\title{
US universities create bridges between physics and biology
}

[WASHINGTON] A number of leading US research universities are planning new institutes to bring physical and biomedical scientists together. This reflects a growing feeling that these fields should be linked more closely in both research and teaching.

One of the largest initiatives comes from Stanford University, where the Nobelprizewinning physicist Steven Chu and biochemist James Spudich are spearheading a proposal for a research centre housing $50 \mathrm{fac}$ ulty members, spanning disciplines from applied physics to clinical medicine.

Multidisciplinary research centres are also planned at the University of Chicago, which is setting up an 'interdivisional institute' straddling the biological and physical sciences, and the University of California at Berkeley, which is planning a building for its bioengineering department and some faculty members from molecular biology and several physical science departments.

In addition, Princeton University is due to announce plans this week for an interdisciplinary genomics institute in a new $\$ 40$ million building connected to its molecular biology department.

About 10 of the 50 posts in the Stanford institute would be new positions. The proposal, which the university administration supports, calls for a new building of 200,000 square feet, which would make it one of Stanford's largest research centres.

University staff declined to estimate the project's cost. But the building alone would cost "tens of millions of dollars", according to Charles Kruger, dean of research.

Although some hurdles - including raising outside funds - remain to be cleared

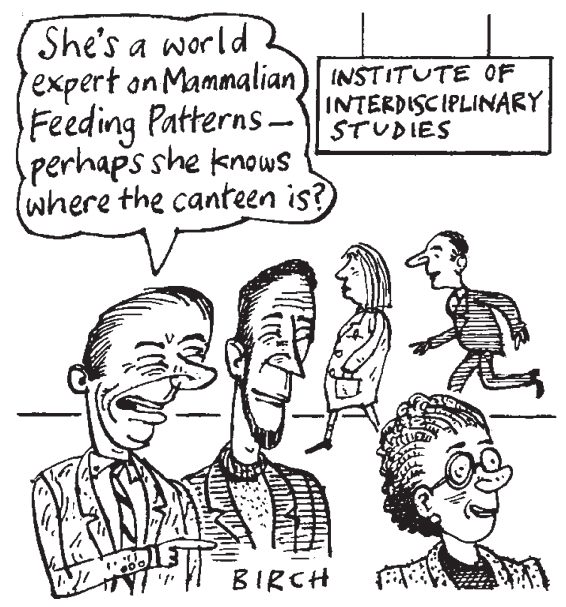

before the centre can receive formal approval from Stanford's board of trustees, its supporters expect the plan to go ahead, and hope to have the new building by 2002 .

The project is currently called 'Bio-X', reflecting the desire to mix biologists with researchers from other disciplines, but without an explicit agenda of techniques to be used or problems to be solved.

"We just want to mix smart people together in an interdisciplinary environment, and let nature take its course," says Spudich. The new building will be between the medical school and the science departments, and Spudich hopes it will draw people in from the surrounding buildings.

The promise of the centre has already attracted one prominent new faculty member to Stanford. Princeton biophysicist Steven Block, a pioneer in the use of 'optical tweezers' to study molecular motors, has accepted a joint appointment in Stanford's

\section{France questions Israeli research deal}

[JERUSALEM] Israeli officials have condemned a French-led effort to make Israel's participation in the European Union's fifth Framework research programme conditional on it implementing the "Wye Plantation' agreement reached with the Palestinian Authority in October.

Pierre Lebovics, spokesperson for the French embassy in Tel Aviv, says that, although Israeli participation is desirable in principle, "it is clear that such participation has a political dimension, in the context of furthering the peace process and the implementation of the Wye accords".

But Orna Berry, Israel's chief scientist, describes France's stance as “a flagrant violation of professional integrity". She says she will refuse to co-ordinate Israel's participation in the Framework programme unless an agreement with Israel is signed by the European Union within two weeks.

Berry says that, if the matter is not resolved by mid-January, when the first calls for projects are issued, there will be little sense in Israel participating.

She argues that Israel's strong research community, and her own experience in working with the Palestinians and Jordan, can contribute to European research and development. "The right thing to do is to concentrate on what we have in common and not on what separates us." The issue will be taken up by Europe's Council of Ministers early this month. applied physics and biology departments, starting in September.

Bio- $\mathrm{X}$ is motivated partly by the growing perception that a deeper understanding of complex biological systems will need a more quantitative type of biology that is closely integrated with the physical sciences.

Much of molecular biology already relies on experimental techniques invented by physicists, such as NMR and X-ray diffraction. But as biology becomes more data-rich, it increasingly requires the analytical and computational methods characteristic of the physical sciences.

At the same time, physicists are finding new problems in biology. For example, Chu, who won the Nobel prize for work on laser cooling of trapped atoms, now also works on the behaviour of single protein molecules.

The desire to bring together scientists from different disciplines stems from an awareness that traditional departments can be physical barriers to cross-fertilization. This is part of the thinking behind Princeton's new institute, planned to be built within two years, with about 12 faculty drawn from physics, chemistry, mathematics and engineering, as well as from biology.

Developmental geneticist Shirley Tilghman, the institute's director, says it will focus on what she calls "integrative biology" - the integration of many kinds of information to understand complex biological processes, such as interactions between cells or genes.

"Biology has thrived in the past 50 years by taking things apart and identifying their components," says Tilghman. "But there is a consensus in the field that the time is coming very soon to reverse the process" - to study how these components interact to form complex systems.

Chicago approved its interdivisional institute in June 1997, and two co-directors were appointed last year. A building of more than 200,000 square feet is planned, costing $\$ 110$ million and due to be built by 2002 . It will house not just the 24 faculty members of the new institute (half of whom will be new appointments), but also several existing departments and Howard Hughes investigators.

The new centres should each have an impact on graduate and undergraduate teaching, as well as research. "There is a growing feeling in the biological community that we need to be thinking hard about how to train the next generation of biologists," says Tilghman. She suggests that this training should include more mathematics, physics and chemistry. LauraGarwin 